\title{
КОНТРОЛЛИНГ НАЛОГОВЫХ ОБЯЗАТЕЛЬСТВ В СИСТЕМЕ ВНУТРЕННЕГО КОНТРОЛЯ ФИНАНСОВО-ХОЗЯЙСТВЕННОЙ ДЕЯТЕЛЬНОСТИ ОРГАНИЗАЦИИ
}

\author{
(c) 2020 Шемякина Марина Сергеевна \\ кандидат экономических наук, \\ доцент Кафедры бухгалтерского учета, налогов и экономической безопасности \\ Поволжский государственный технологический университет, Россия, Йошкар-Ола \\ E-mail:sh.marina.s@gmail.com \\ (c) 2020 Шлычков Дмитрий Сергеевич \\ кандидат экономических наук, доцент Департамента учета, анализа и аудита \\ Финансовый университет при Правительстве Российской Федерации, Россия, Москва \\ E-mail: sds457@mail.ru
}

Контроллинг налоговых расчетов одно из новых направлений стратегического управления хозяйственными процессами на уровне корпоративного менеджмента экономического субъекта. Основными элементами контроллинга являются: информационное обеспечение, планирование и контроль. Ввиду того, что налоговые платежи являются неотъемлемой частью хозяйственных операций деятельности организации, а также большое влияние оказывают внешние факторы (налоговая политика со стороны государства), необходим тщательный контроль и управление налоговыми потоками.

Главным результатом исследования является построение модели процесса передачи информации для контроля за учетно-аналитическими данными организации и модели контроллинга организации с применением элементов системы сбалансированных показателей.

Ключевые слова: налоги, сборы, взносы, план счетов бухгалтерского учета, контроллинг, обязательства, налог на прибыль.

Обязательства экономического субъекта перед различными контрагентами являются составной частью финансово-хозяйственной деятельности. Это действия правового характера, передающие экономические выгоды, возникшие в результате прошлых финансово-хозяйственных операций или событий.

Структура обязательств носит временной характер, то есть согласно бухгалтерскому балансу, который является одним из основных форм бухгалтерской отчетности, обязательства экономического субъекта классифицируются на долгосрочные и краткосрочные.

Долгосрочные обязательства - обязательства срок погашения которых превышает один год. К ним относятся кредиты и займы со сроком погашения более одного года.

Краткосрочные обязательства - обязательства срок погашения которых не превышает один год. К ним относятся кредиты и займы со сроком погашения не более одного года, задолженность перед такими контрагентами как поставщики, работники организации, обязательства по налогам и сборам, прочие кредитные обязательства.

Особое внимание менеджеры организации уделяют краткосрочным обязательствам ввиду того что управление ими является сложным экономическим процессом. Они требуют более детальной проработанности, подвержены изменениям внешней среды (экономическая и социальная политика страны, экология, эпидемиология и другие факторы). 
Управление обязательствами экономического субъекта требует различного подхода и усилий:

\begin{tabular}{|l|l|l|}
\hline \multicolumn{1}{|c|}{ Обязательства } & \multicolumn{1}{c|}{ Законодательство } & \multicolumn{1}{c|}{ Уровень управления } \\
\hline Поставщики и подрядчики & Гражданское & Простое \\
\hline Оплата труда & Трудовое & Умеренное \\
\hline Налоги и сборы & Налоговое & Сложное \\
\hline
\end{tabular}

Одним из сложных управлений являются налоговые обязательства. Факторы сложности это:

1. ведение переговоров - руководитель налоговой службы в первую очередь нацелен на собираемость налогов, что является результативностью его работы, следовательно, договориться об отсрочке платежа крайне маловероятно;

2. уплата налоговых обязательств третьими лицами - сложность возникает в составлении трехстороннего соглашения между экономическими субъектами;

3. организация системы контроля и учета налоговых обязательств - создание единой системы бухгалтерского и налогового учета.

Таким образом, в целях эффективной финансово-хозяйственной деятельности экономического субъекта, необходимо организовать систему внутреннего контроля налоговых обязательств, а также контроллинг налоговых обязательств.

Для построения системы управления налоговыми обязательствами необходимо обратиться к понятийному аппарату: «налог», «сбор» и «страховой взнос», данные термины представлены в Налоговом кодексе РФ статье 8. Следуя из представленных определений можно выделить следующие ключевые позиции:

- обязательный платеж или взнос;

- носящий безвозвратный и безвозмездный характер;

- финансирование деятельности государственных структур.

Кроме того, необходимо отметить отличительную особенность «сбора» от «налога» - это плата за совершение значимых правовых действий в отношении плательщика сбора, например, получение лицензии, подача исковых заявлений и другие юридически значимые действия.

Исходя из представленных терминов «налог», «сбор» И «страховой взнос» видно, что любой экономический субъект в добровольной форме отчуждает свои собственные средства в доход государства. При этом государство осуществляет контроль за поступлением денежных средств в виде налогов и сборов согласно Налогового кодекса РФ.

Для эффективного взаимодействия с государственными органами экономическому субъекту необходимо организовать эффективную и действенную систему внутреннего контроля.

Главным источником информации при определении уровней реализации системы внутреннего контроля налоговых обязательств служат данные налогового и бухгалтерского учета. Следует отметить, что они опираются на различные нормативные правовые базы:

- бухгалтерский учет ведется в соответствии с Федеральным законом от 06.12.2011 г. № 402-Ф3 «О бухгалтерском учете», положениями по бухгалтерскому учету, методическими указаниями, учетной политикой;

- налоговый учет - основан на НК РФ и приказах Минфина России и ФНС России, разъясняющих отдельные нормы.

В связи с этим необходимо отметить, что при ведении финансово-хозяйственной деятельности у организации в части отражения хозяйственных операций могут возникнуть расхождения между бухгалтерским и налоговым учетом, что в последствии приводит к возникновению постоянных и/ или отложенных налоговых обязательств и активов.

Отражение обязательств по налогам и сборам, подлежащим к уплате в бюджет и внебюджетные фонды, происходит на счетах 68 «Расчеты по налогам и сборам», 69 «Расчеты по социальному страхованию и обеспечению», 19 «Налог на добавленную стоимость по приобретенным ценностям» согласно Плану счетов бухгалтерского учета финансово-хозяйственной деятельности организации, утвержденному приказом Минфина России от 31.10.2000 № 94н (рис. 1-3). 
Счет 19

\begin{tabular}{|c|c|}
\hline $\begin{array}{l}\text { Сальдо начальное - НДС не принятый к } \\
\text { возмещению на начало месяца }\end{array}$ & \\
\hline «Входящий» НДС & Возмещенный НДС \\
\hline Оборот & Оборот \\
\hline $\begin{array}{l}\text { Сальдо конечное - НДС не принятый к } \\
\text { возмещению на конец месяца }\end{array}$ & \\
\hline
\end{tabular}

Рис. 1. Счет бухгалтерского учета № 19 «Налог на добавленную стоимость».

Счет 68

\begin{tabular}{|c|c|}
\hline \multirow[b]{2}{*}{ Уплачены налоги } & $\begin{array}{l}\text { Сальдо начальное - задолженность перед бюджетом } \\
\text { на начало месяца }\end{array}$ \\
\hline & Начислены налоги \\
\hline \multirow[t]{2}{*}{ Оборот } & Оборот \\
\hline & $\begin{array}{l}\text { Сальдо конечное - задолженность перед бюджетом } \\
\text { на конец месяца }\end{array}$ \\
\hline
\end{tabular}

Puc. 2. Счет бухгалтерского учета № 68 «Расчеты по налогам и сборам». 


\section{Счет 69}

\begin{tabular}{r|l}
\hline & $\begin{array}{l}\text { Сальдо начальное - задолженность перед бюджетом } \\
\text { на начало месяца }\end{array}$ \\
\cline { 2 - 2 } Уплачены CB & Начислены СВ \\
\hline Оборот & Оборот \\
\hline & $\begin{array}{l}\text { Сальдо конечное - задолженность перед бюджетом } \\
\text { на конец месяца }\end{array}$ \\
\hline
\end{tabular}

Рис. 3. Счет бухгалтерского учета № 69 «Расчёты по социальному страхованию и обеспечению».

Налог на добавленную стоимость является одним из значимых налогов. Ввиду того что данный налог по собираемости является основным в доходной части государства, контроль за его собираемостью в последнее время усилился. Можно сказать, что контроль осуществляет искусственный интеллект. В организации необходимо четко наладить информационные процессы - это включает:

1. отражение в учете входящих (Дт. 19 Кт. 60 (76)) и исходящих (Дт. 90.3 Кт 68) счет-фактур - первичный учет;

2. регистрация счет-фактур в книге продаж и покупок - регистры налогового учета;

3. правильно принять к вычету (возмещению) НДС (Дт. 68 Кт. 19);

4. составить налоговую отчетность - декларацию по НДС.

Правильно выстроенные информационные потоки учета НДС послужат эффективной работе программного обеспечения отражения операций по налогу.

Счета бухгалтерского учета 68 и 69 являются информативными в части отражения на них налогов и страховых взносов. Счет 68 отражает такие налоги как:

- налог на прибыль, при этом идет взаимосвязь со счетами 99 «Прибыли и убытки», 09 «Отложенные налоговые активы», 77 «Отложенные налоговые обязательства»;

- налог на доходы физических лиц - взаимосвязь со счетом 70 «Расчеты с персоналом по оплате труда»;

- налог на добавленную стоимость - взаимосвязь со счетом 19 «Налог на добавленную стоимость»;

- имущественные налоги (земельный налог, налог на имущество, транспортный налог) - взаимосвязь со счетами затрат или со счетом 91 «Прочие доходы и расходы»;

- другие налоги.

Счет 69 менее информативен, но не меньше значим чем счет 68. На нем находят отражение следующие сборы:

- пенсионное страхование;

- медицинское страхование;

- социальное страхование;

Начисленные сборы оказывают влияние на себестоимость продукции, то есть на счета затрат организации. Особое внимание необходимо уделять информации, которая позволяет минимизировать начисление страховых взносов.

Организация начисления и уплаты налогов и сборов и отражение их на счетах 68 и 69 является идентичной. С одной стороны, по дебету данных счетов отражаются выполненные обязательства 
организации по уплате налогов и сборов, с другой стороны по кредиту счетов отражаются обязательства (задолженность) по уплате налогов и сборов, невыполнение которых может привести к таким последствиям как штрафные санкции, санкции в виде пеней, а также вплоть до административных и уголовных санкций.

Таким образом необходимо сказать, что требуется эффективная проработанность взаимодействия информации между счетами учета с применением современных информационных технологий.

Современная система налогового учета формировалась на основе учетно-аналитического информационного обеспечения экономического субъекта. Следствием этого учет для целей налогообложения трансформировался в налоговый учет и утверждением 25 главы Налогового кодекса РФ.

Налоговый учет как термин закреплен в статье 313 Налогового кодекса РФ - это система обработки первичных документов с целью получения информации, определяющей налоговую базу по налогу с соблюдением требований налогового законодательства. Законодатель дает определенные свободы экономическому субъекту для разработки системы налогового учета, но при этом с соблюдением принципов: денежного измерения, имущественной обособленности, непрерывности деятельности организации, временной определённости фактов хозяйственной деятельности, последовательности применения норм и правил налогового учёта, равномерности признания доходов и расходов.

Информационные потоки хозяйственных операций должны быть организованы так, чтобы обрабатываемая информация давала возможность отражать операцию в двух параллелях - налоговом и бухгалтерском учете с применением единых принципов:

- последовательности отражения фактов хозяйственной деятельности организации;

- системности отражения доходов и расходов организации;

- регистрации результатов деятельности в налоговой отчетности, в том числе в декларации по налогу на прибыль.

Основное значение необходимо уделить доходом и расходом организации, так как одна и та же операция будет отражена с учетом требований Налогового кодекса РФ (25 глава) и Положений по бухгалтерскому учету (ПБУ 9/99 и ПБУ 10/99).

Правила признания доходов и расходов, установленные главой 25 Налогового кодекса, отличаются от правил, по которым учитываются доходы и расходы в бухгалтерском учете согласно ПБУ 9/99 и ПБУ 10/99. В связи с этим законодательство требует вести учет разниц в бухгалтерских и налоговых доходах и расходах, а также корректировать сумму налога по бухгалтерскому учету до суммы, заявленной в налоговой декларации. Как это делать, прописано в ПБУ 18/02.

По ПБУ 18/02 налог на бухгалтерскую прибыль называется условным расходом. А налог на бухгалтерский убыток - условным доходом.

Формулы для их расчета:

Условный расход = Бухгалтерская прибыль * Ставка налога на прибыль

Условный доход = Бухгалтерский убыток * Ставка налога на прибыль

Отражается условный расход или доход на специальном субсчете к счету 99 «Прибыли и убытки»:

\begin{tabular}{|c|c|}
\hline $\begin{array}{c}\text { начислен условный расход по налогу } \\
\text { на бухгалтерскую прибыль }\end{array}$ & начислен условный доход по налогу на прибыль \\
\hline $\begin{array}{l}\text { ДЕБЕТ } 99 \text { субсчет «Условный расход по налогу на } \\
\text { прибыль» } \\
\text { КРЕДИТ } 68 \text { субсчет «Расчеты по налогу на прибыль» }\end{array}$ & $\begin{array}{l}\text { ДЕБЕТ } 68 \text { «Расчеты по налогу на прибыль» } \\
\text { КРЕДИТ } 99 \text { субсчет «Условный доход по налогу на } \\
\text { прибыль» }\end{array}$ \\
\hline
\end{tabular}

Полученный в бухгалтерском учете условный доход или расход необходимо откорректировать до суммы текущего налога на прибыль. Для этого надо найти и отразить в бухгалтерских записях разницы между бухгалтерской и налогооблагаемой прибылью или убытком, которые отражены в регистрах учета в результате отличных правил учета доходов и расходов. Разницы могут быть постоянными или временными. Постоянные разницы - это доходы или расходы, которые формируют бухгалтерскую прибыль, но не признаются в налоговом учете ни в отчетном, ни в последующих периодах - никогда, ни при каких обстоятельствах. Временные разницы признаются в различные периоды времени, то есть, момент признания расходов и/или доходов в бухгалтерском суммы признаются в одном отчетном периоде, а в налоговом учете - в другом периоде. Но в конечном итоге 
они все равно будут учтены как при расчете бухгалтерской, так и при расчете налогооблагаемой прибыли. Вопрос во времени - раньше или позже.

Постоянные разницы возникают, когда бухгалтерские расходы или доходы не признаются в налоговом учете. И наоборот - когда налоговые доходы или расходы не признаются в целях бухгалтерского учета.

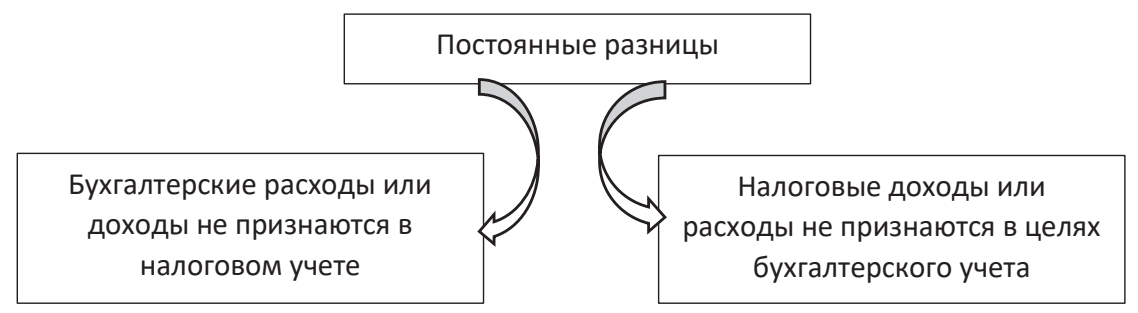

Например, расходы, которые в целях налогообложения прибыли списываются по определенным нормативам, а в бухгалтерском учете - в полной сумме.

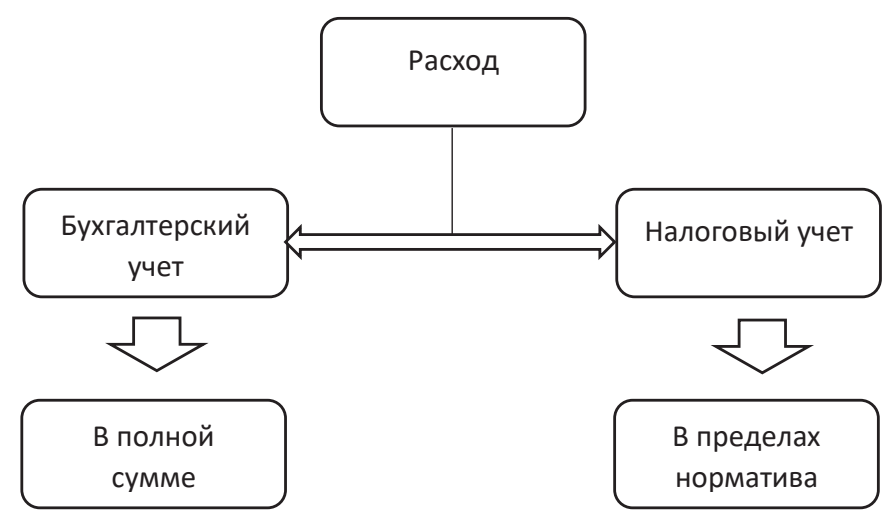

Если из-за постоянных разниц бухгалтерская прибыль оказалась больше налогооблагаемой, то и налог на бухгалтерскую прибыль больше, чем в налоговом учете. А значит, начисленный в бухгалтерском учете налог надо уменьшить. Следовательно, получаемую разницу умножают на ставку налога на прибыль, что и приводит к результату равному постоянному налоговому активу.

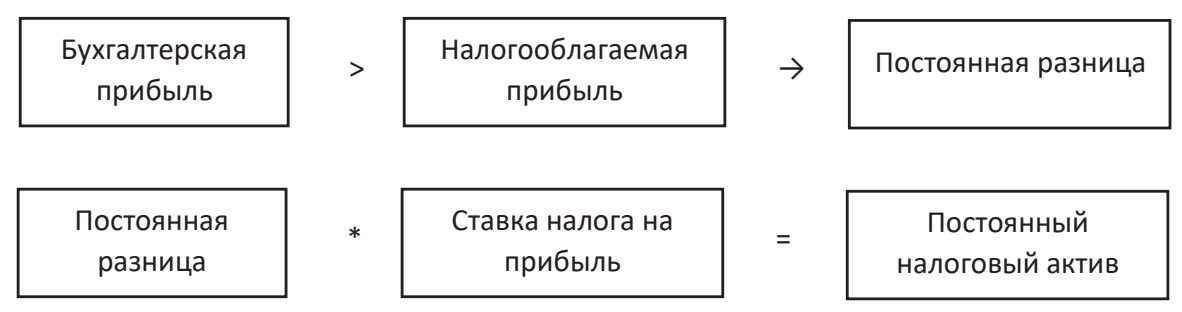

Начисляют его бухгалтерской записью: 
Если из-за постоянных разниц бухгалтерская прибыль оказалась меньше налогооблагаемой, то и налог на бухгалтерскую прибыль соответственно меньше, чем в налоговом учете. А значит, его надо увеличить. Производится следующий расчет: разницу между налоговой и бухгалтерской прибылью умножают на ставку налога на прибыль, что приводит к получению постоянного налогового обязательства:

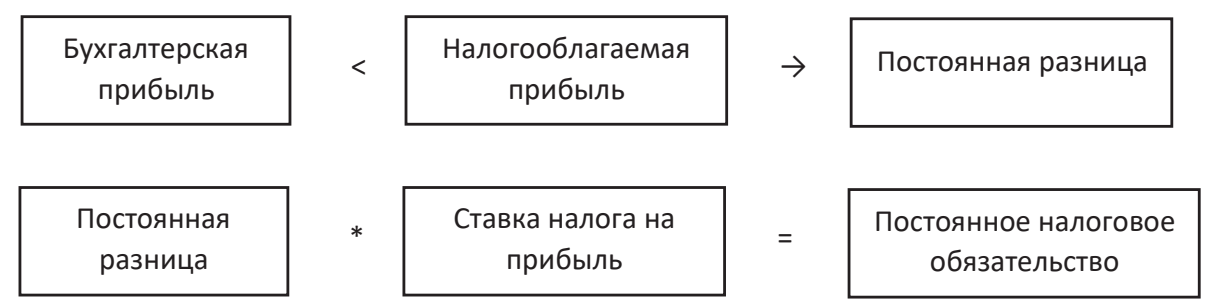

Начисляют его бухгалтерской записью:

ДЕБЕТ 99 субсчет «Постоянное налоговое обязательство» КРЕДИТ 68 субсчет «Расчеты по налогу на прибыль»

начислено постоянное налоговое обязательство

Это были постоянные разницы, а бывают еще и временные.

Временные разницы, как и упоминалось, образуются в результате различий в моменте признания хозяйственных операций во времени:

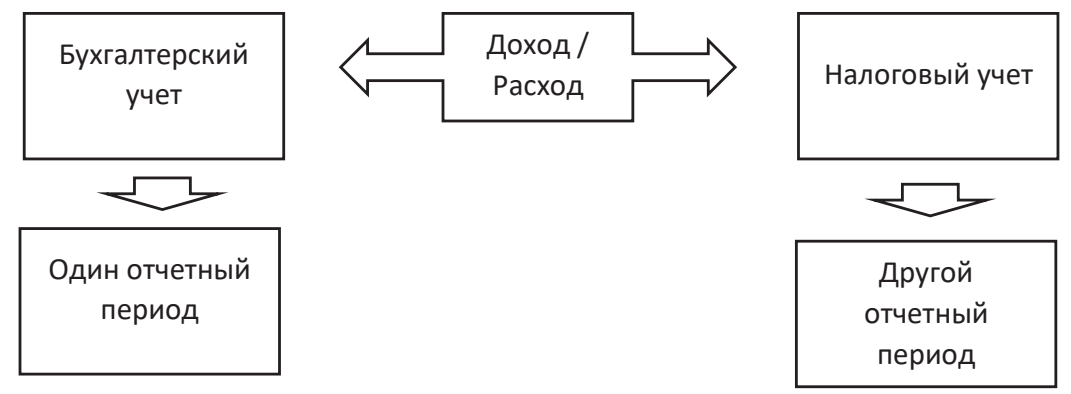

Выделяют следующие временные разницы: вычитаемые и налогооблагаемые:

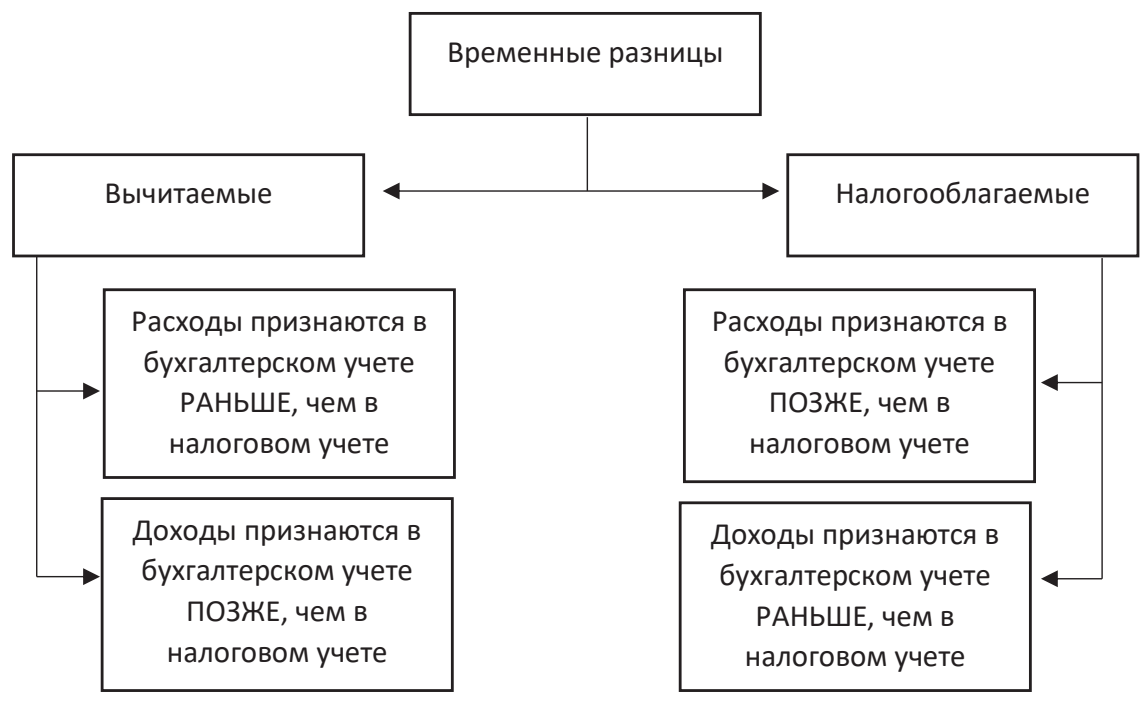


Вычитаемые временные разницы возникают в следующих случаях:

- амортизация по бухгалтерскому учету больше начисленной амортизации по налоговому учету;

- в налоговом учете применяется кассовый метод, неоплаченные расходы, полученные авансы;

- убыток прошлого года списан в бухгалтерском учете единовременно в отчетном периоде, а в налоговом учете перенесен на будущее годы.

Здесь везде бухгалтерская прибыль окажется меньше прибыли в налоговом учете. Поэтому налог на бухгалтерскую прибыль в отчетном периоде меньше, чем в налоговом учете. А значит, его надо увеличить. Для этого вычитаемую временную разницу умножают на ставку налога на прибыль и получают отложенный налоговый актив:

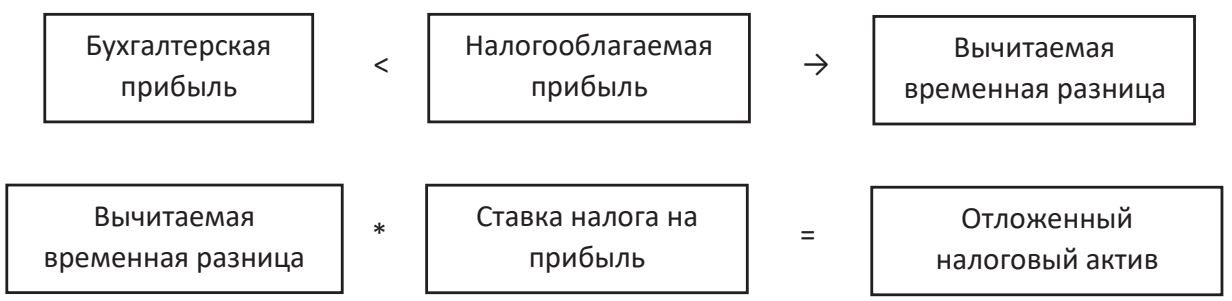

В последующем он уменьшит налоговые поступления в бюджет за счет того, что расходы все-таки будут признаны в налоговом учете, а доходы - в бухгалтерском.

Начисляется такой актив бухгалтерской записью:

Возникают случаи налогооблагаемых временных разниц:

- амортизация в бухгалтерском учете меньше амортизации начисленной по налоговому учету;

- в налоговом учете - кассовый метод. Не полученную фактически выручку, проценты, штрафные санкции компания в доходах не отразила, а в бухгалтерском учете учла;

- проценты по заемным средствам включаются в первоначальную стоимость объекта, а в налоговом учете списываются единовременно.

Во всех этих случаях бухгалтерская прибыль оказывается больше налоговой. Поэтому налог на бухгалтерскую прибыль в отчетном периоде больше, чем в налоговом учете. А значит, его надо уменьшить. Для этого налогооблагаемую временную разницу умножают на ставку налога на прибыль и получают отложенное налоговое обязательство:

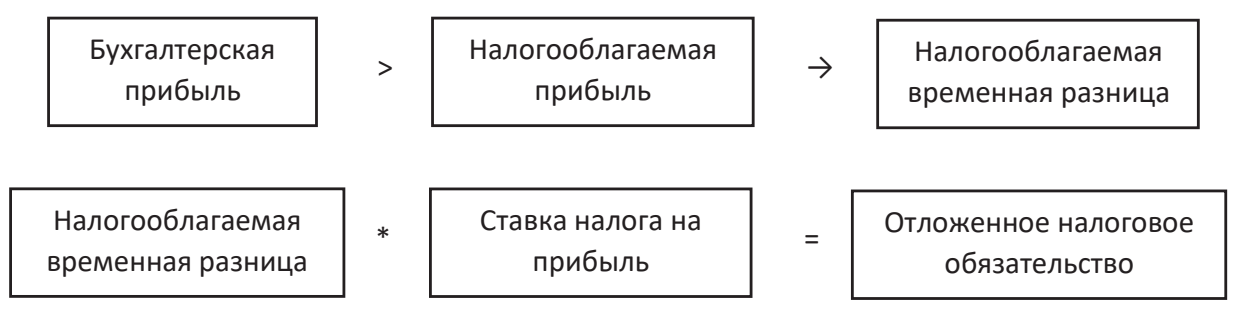

В последующем оно увеличит налоговые поступления в бюджет за счет того, что расходы все-таки будут признаны в бухгалтерском учете, а доходы - в налоговом.

Начисляется такое обязательство бухгалтерской записью: 
С учетом выявленных постоянных и временных разниц, в бухгалтерском учете условный налог на прибыль должен быть откорректирован и приведен к сумме налога, полученной по данным налогового учета. Посмотрим формулу, по которой надо это сделать, и соответствующие корреспонденции счетов в бухгалтерском учете.

\section{Текущий налог на прибыль}

= Условный расход (+) или Условный доход (-)

+ Постоянное налоговое обязательство

- Постоянный налоговый актив

+ Отложенный налоговый актив

- Отложенное налоговое обязательство

На бухгалтерских записях эта корректировка выглядит так:

\begin{tabular}{|l|l|}
\hline $\begin{array}{l}\text { ДЕБЕТ } 99 \text { субсчет «УсловныЙ расход по налогу на прибыль» } \\
\text { КРЕДИТ } 68 \text { субсчет «Расчеты по налогу на прибыль» }\end{array}$ & $\begin{array}{l}\text { начислен условный расход по налогу на } \\
\text { бухгалтерскую прибыль }\end{array}$ \\
\hline $\begin{array}{l}\text { ДЕБЕТ } 99 \text { субсчет «Постоянное налоговое обязательство» } \\
\text { КРЕДИТ } 68 \text { субсчет «Расчеты по налогу» }\end{array}$ & $\begin{array}{l}\text { начислено постоянное налоговое } \\
\text { обязательство }\end{array}$ \\
\hline $\begin{array}{l}\text { ДЕБЕТ } 09 \\
\text { КРЕДИТ } 68 \text { субсчет «Расчеты по налогу на прибыль» }\end{array}$ & начислен отложенный налоговый актив \\
\hline $\begin{array}{l}\text { ДЕБЕТ } 68 \text { субсчет «Расчеты по налогу на прибыль» } \\
\text { КРЕДИТ } 99 \text { субсчет «Постоянный налоговый актив» }\end{array}$ & начислен постоянный налоговый актив \\
\hline $\begin{array}{l}\text { ДЕБЕТ } 68 \text { субсчет «Расчеты по налогу на прибыль» } \\
\text { КРЕДИТ } 77\end{array}$ & $\begin{array}{l}\text { начислено отложенное налоговое } \\
\text { обязательство }\end{array}$ \\
\hline
\end{tabular}

Отложенный налоговый актив и отложенное обязательство указываются в балансе - активе и пассиве соответственно. Их изменения - в отчете о финансовых результатах. Там же приводится сумма текущего налога на прибыль, в том числе постоянное налоговое обязательство и постоянный налоговый актив.

При разработке информационной системы налогового учёта, основанной на данных бухгалтерского учёта, необходимо:

1. Определить объекты учёта и соотнести их с учетными системами: объекты, подверженые единым правилам обоих систем учета и объекты, которые требуют особого учета в разрезе систем учета.

2. Разработать и регламентировать порядок использования данных бухгалтерского учёта в целях реализации системы налогообложения.

3. Разработать формы аналитических регистров налогового учёта для выделенных объектов налогового учёта.

Процесс построения системы внутреннего контроля за объектами учета должен быть реализован и обобщен с применение двух систем учета: бухгалтерского и налогового.

Контроль данных должен осуществляться на последнем этапе формирования отчетности организации. В общем виде процесс информационных потоков передачи данных для контроля можно представить в виде, показанном на рис. 4.

Информационное обеспечение организации - это процесс получения, обработки и анализа данных результатом которого является формирование полной и достоверной отчетности организации. Из рис. 4 видно, что контроль данных осуществляется на этапе формирования бухгалтерской и налоговой отчетности. Данные отчетности должны быть сопоставимы, если результат контроля данных не удовлетворителен, то необходимо внесение исправлений и изменений на этапе обработки данных первичной информации, если результат положительный, то данные отчетности организации могут быть использованы внешними пользователями информации. 


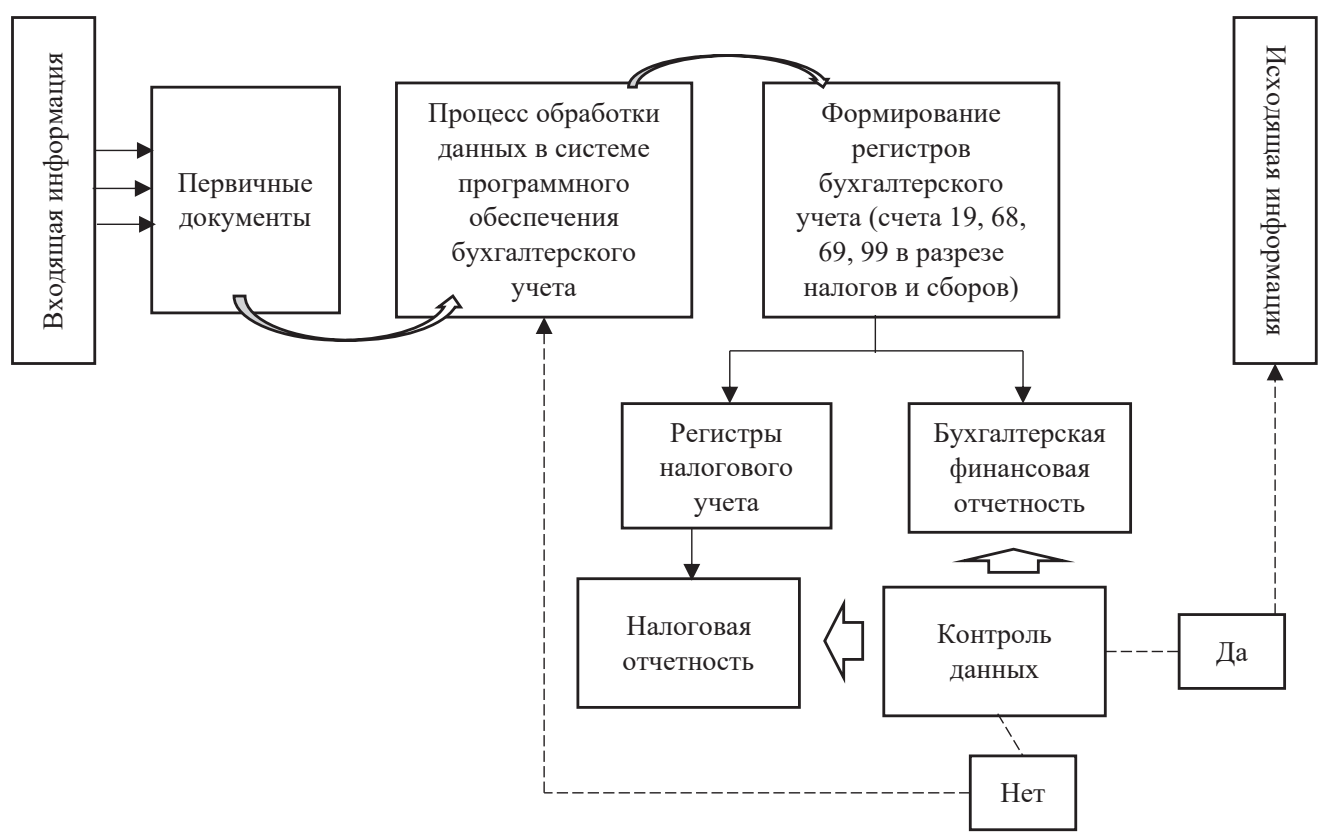

Puc. 4. Модель процесса передачи информации для контроля за учетно-аналитическими данными организации.

Реализуя методы контроля хозяйственных процессов организации необходимо так же обратиться к международной практике ведения бизнеса.

Процесс организации системы учетно-аналитической информации в международной практике основывается на единых подходах в системе бухгалтерского учета. Однако имеются свои особенности и сложности среди которых можно выделить группы международных органов, реализующих политику в области учетных данных:

1. органы, регулирующие деятельность инвесторов (Комиссия по ценным бумагам и биржам (SEC) - США, Австралийская комиссия по ценным бумагам и инвестициям (ASIC) и Управление по надзору за финансовыми услугами (FSA) - Великобритания);

2. органы, утверждающие стандарты бухгалтерского учета (Совет по стандартам финансового учета (FASB) - США, Совет по международным стандартам финансовой отчетности (IASB)).

Однако необходимо отметить, что последние органы ведут работу между своими стандартами на их единообразие и гармонизацию.

Одним из основных нормативно-правовых актов, оказывающих наиболее сильное влияние на управление налогообложением в компаниях, является статья 404 закона Сарбейнса-Оксли. Согласно этой статье «компании, ценные бумаги которых обращаются на биржах США, обязаны включать в состав годовой отчетности отчет о состоянии системы внутреннего контроля, в котором:

- содержится заявление об ответственности руководства за создание и поддержание системы внутреннего контроля за подготовкой и представлением финансовой отчетности;

- приводится обоснование оценки руководством эффективности системы внутреннего контроля по состоянию на конец финансового года;

- приводится заключение внешнего аудитора в отношении такой оценки в соответствии со стандартами, утвержденными Советом по надзору за отчетностью публичных компаний (РСАОВ)» [5].

В большинстве юрисдикций данные налоговой отчетности на момент выпуска финансовой отчетности носят оценочный характер, поскольку декларация по налогу на прибыль еще не заполнена, а времени на детальную проработку вопроса нет. Учет отсроченных налогов требует оценки будущих платежей, которые предстоит внести в условиях определенного налогового режима за операции, отраженные в отчетности текущего года. Однако благодаря изменениям в сфере корпоративного управления значительно снизился допуск на ошибки в налоговой отчетности, и финансовый ди- 
ректор и совет директоров обычно рассчитывают на «отсутствие неожиданностей» при внесении изменений.

Публикация Интерпретации № 48 (FIN 48) с разъяснением особенностей применения стандарта налогового учета FAS 109 в рамках Общепринятых принципов бухгалтерского учета США (US GAAP) привела к значительному ужесточению требований к резервам для уплаты налогов компаниями, зарегистрированными Комиссией по ценным бумагам и биржам (SEC) CША, и их дочерними структурами. Интерпретация № 48 требует более строгого подхода к признанию и раскрытию неопределенных налоговых позиций в рамках применения Общепринятых принципов бухгалтерского учета США. Кроме того, Комитет по международным стандартам финансовой отчетности принимает меры по ужесточении международного стандарта признания и раскрытия информации в целях налогового учета IAS 12.

В целях понимания процессов получения учетных данных и систем внутреннего контроля над такими процессами необходимо ответить на следующие вопросы:

- каков уровень неопределенности при интерпретации или применении налогового закона (законов), регламентирующего исчисление налогов;

- каково качество данных, получаемых или используемых в сделках, операционной сфере и в сфере соблюдения законодательства;

- существуют ли вопросы или проблемы, связанные с интерпретацией налогового законодательства применительно к имеющимся данным;

- какие резервы необходимы, чтобы застраховаться от перечисленных факторов неопределенности;

- какой уровень существенности является приемлемым?

Построение любой модели завязано на использовании различных приемов и методов. В целях эффективной работы организации, т.е. достижения стратегических показателей, необходимо применение современных подходов к построению управленческой модели контроллинга организации. Современным методами являются:

1. система сбалансированных показателей. Элементами данного метода являются - финансовый аспект, ориентация на потребителя, внутренние бизнес-процессы, обучение и перспектива роста;

2. контроллинг - элементы: планирование, контроль, информационное обеспечение.

На рисунке 5 представлена модель контроллина организации, включающая в себя систему сбалансированных показателей.

Налоговый контроллинг - современная концептуальная система управления, порожденная практикой современного эффективного менеджмента. Это обобщающая система элементов системной интеграции методов, технологий, инструментальных средств автоматизированного управления сложными организационными, экономическими и техническими объектами или процессами (рис. 6). Формирование единой и эффективно функционирующей системы контроллинга, которая может включать в себя как финансовую, так и нефинансовую информацию, необходимо для решения вопроса автоматизации обработки информационных данных. Управление информационными потоками в системе контроллинга возможно только при создании единых управленческих бизнеспроцессов учетно-информационной системы.

В результате внедрение автоматизированной системы контроллинга должно освободить руководителей от необходимости постоянного, детального изучения и анализа условий для решения части стандартных задач. Контроллинговые методы в управленческой структуре организации должны повысить эффективность и надежность реализации стратегии деятельности, оптимизировать технологию и поддержку стратегического и оперативного управления учетных данных в системе бухгалтерского и налогового учета и анализа. 


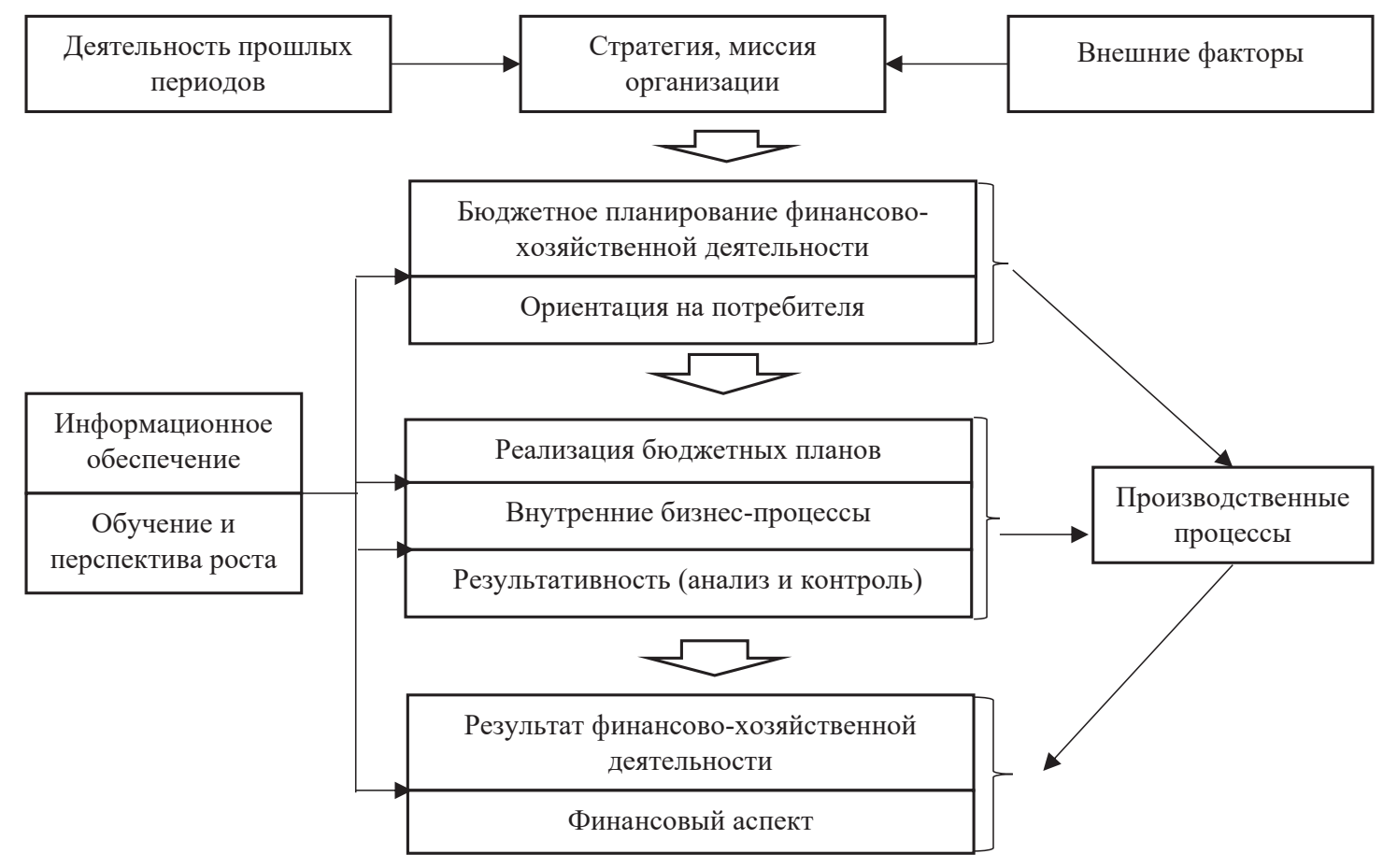

Рис. 5. Модель контроллинга организации.

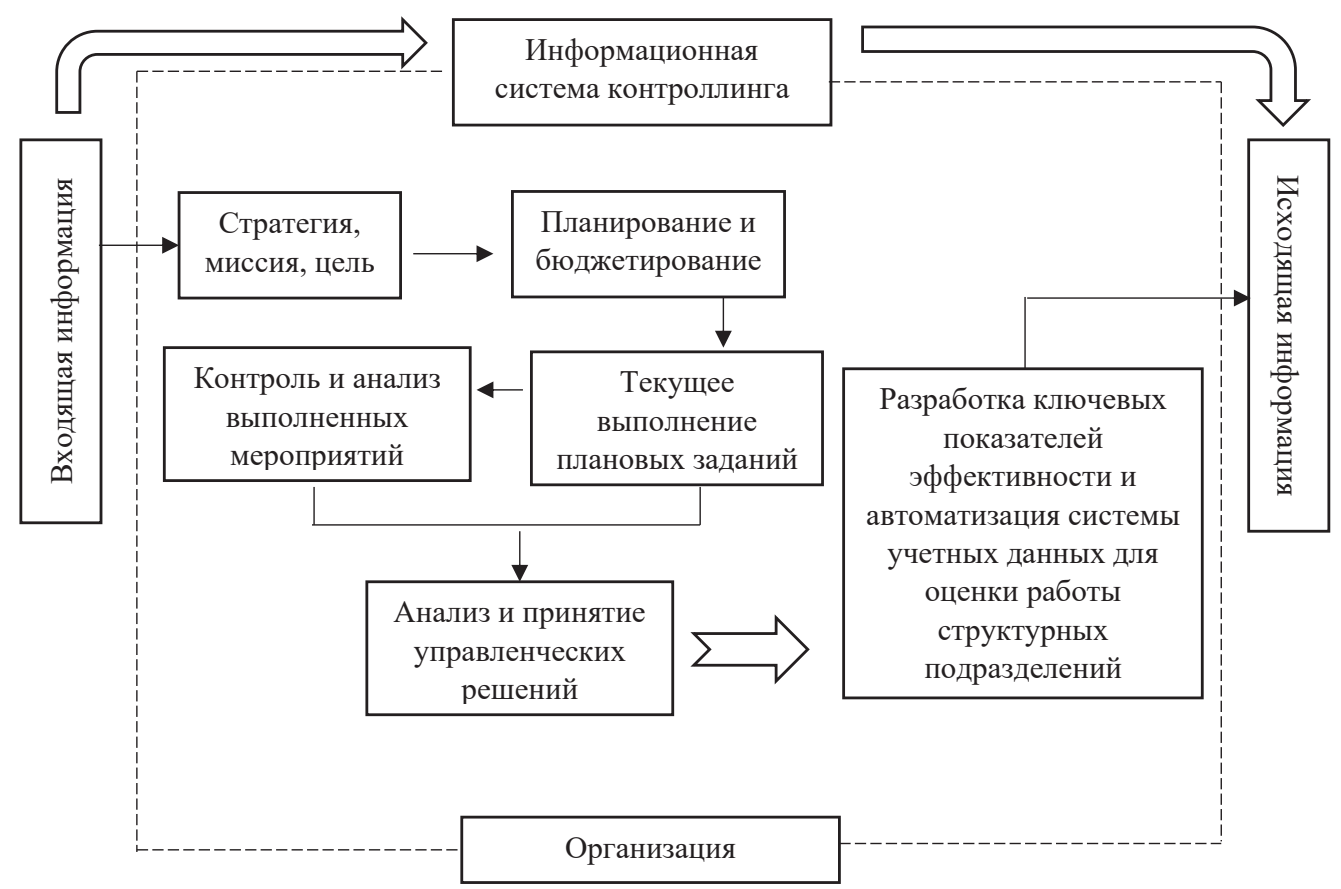

Puc. 6. Контроллинг - поставщик информации для руководства. 


\section{Библиографический список}

1. Ильин А. Ю. Горизонтальный мониторинг - новый метод в системе налогового контроля [Электронный ресурс] // Аналитический портал «Отрасли права».- 2015.- 24 aпр._ URL: http://xn--7sbbaj7auwnffhk.xn p1ai/article/1471

2. Концепция контроллинга: Управленческий учет. Система отчетности. Бюджетирование / Horvath \& Partners; Пер. с нем.-4-е изд.-М.: Альпина Паблишерз, 2009._-269 с.

3. Налоговый кодекс Российской Федерации. Часть вторая [Электронный ресурс]: от 13.07.2015 № 214- Ф3, № 232-Ф3 (ред. от 10.10.2016) // Консультант Плюс. - Режим доступа: http:/www.consultant.ru/.

4. Рамазанова A.P. Налоговый контроллинг в системе стратегического управления // В мире науки и инноваций. Сборник статей международной научно-практической конференции: в 5 частях. - 2017. С. 16-19.

5. Эффективное управление налогообложением: Будущее корпоративной налоговой службы / Тони Элгуд, Тони Фултон, Марк Шуцман; Пер. с англ.—М.: Альпина Паблишер, 2012.- 334 с. 